\title{
NUMB wt Allele
}

National Cancer Institute

\section{Source}

National Cancer Institute. NUMB wt Allele. NCI Thesaurus. Code C101636.

Human NUMB wild-type allele is located in the vicinity of 14q24.3 and is approximately $183 \mathrm{~kb}$ in length. This allele, which encodes protein numb homolog, is involved in neuronal development. 